\title{
TFG/ALK Long Form Fusion Protein
}

National Cancer Institute

\section{Source}

National Cancer Institute. TFG/ALK Long Form Fusion Protein. NCI Thesaurus. Code C101081.

A fusion protein (756 aa, 84 kDa) encoded by the TFG/ALK long form fusion gene. This protein is comprised of the $\mathrm{N}$-terminal third of protein TFG, including the coiled-coil oligomerization domain, fused to the cytoplasmic domain of the ALK tyrosine kinase receptor protein. 